\title{
I.I. Мигаль
}

\section{Гемодинаміка при корекції лійкоподібної деформації грудної клітки за Nuss}

Львівський національний медичний університет імені Данила Галицького, Украйна

Paediatric surgery.Ukraine.2020.3(68):7-14; DOI 10.15574/PS.2020.68.7

For citation: Myhal II. (2020). The hemodynamics during the Nuss procedure for repair of pectus excavatum. Paediatric Surgery.Ukraine. 3(68):7-14; doi 10.15574/PS.2020.68.7

Актуальність. На гемодинамічні показники під час корекції лійкоподібної деформації грудної клітки (ЛДГК) за Nuss впливають як хірургічні маніпуляції, так і компоненти анестезії, особливо регіонарної.

Мета: дослідження аналізу гемодинамічних показників під час корекції ЛДГК за Nuss в умовах комбінації загальної анестезії з різними варіантами регіонарних блокад.

Матеріали і методи. У обсерваційне проспективне дослідження включено 60 підлітків (хлопчики/дівчатка $=47 / 13)$, які оперовані з приводу ЛДГК в умовах комбінації загальної анестезії з регіонарними блоками. Пацієнти рандомізовані на три групи по 20 у кожній у залежності від методу регіонарного знеболювання: стандартна епідуральна анестезія на рівні максимальної деформації (CEA), висока епідуральна анестезія (BEA) на рівні Th2-Th3 та білатеральна паравертебральна анестезія (ПВА). Тяжкість деформації за індексом Haller серед усіх пацієнтів становила 3,9 [3,6-4,1]. Аналізували артеріальний тиск (AT), частоту серцевих скорочень (ЧСС).

Результати. СЕА викликала значне зниження АТ до 30\% від вихідного рівня до початку операції. У групі ВЕА зниження АТ було менш виразним. А в групі ПВА АТ майже не змінився під впливом анестезії. Елевація груднини та капноторакс підвищили АТ без збільшення ЧСС. Момент повертання корегуючої пластини здійснив незначний вплив на гемодинамічні показники, хоч і вважається найбільш травматичним моментом даної операції. На тлі ПВА спостерігалось незначна тахікардія, АТ зазнав мінімальних змін, та об’єм інтраопераційної інфузії був найменшим. ВЕА характеризувалась більш стабільним гемодинамічним профілем, порівняно з СЕА. Наприкінці операції у всіх групах гемодинамічні показники практично повернулись до вихідного рівня.

Висновки. Під час корекції ЛДГК за Nuss зниження АТ найбільш виразне на тлі CEA на рівні максимальної деформації, помірне - на тлі ВЕА, та практично відсутнє - на тлі білатеральної ПВА. Епідуральна анестезія викликає зниження ЧСС, та ПВА практично не впливає на ЧСС. Елевація груднини, капноторакс супроводжуються деяким підвищенням АТ. Показники гемодинаміки перед операцією та анестезією у пацієнтів з ЛДГК не корелюють з тяжкістю деформації за індексом Haller.

Дослідження було виконане відповідно до принципів Гельсінської Декларації. Протокол дослідження погоджений Локальним етичним комітетом установи. На проведення дослідження було отримано інформовану згоду батьків та дітей.

Автор заявляє про відсутність конфлікту інтересів.

Ключові слова: гемодинаміка, лійкоподібна деформація грудної клітки, операція Nuss, епідуральна анестезія, паравертебральна анестезія.

\section{The hemodynamics during the Nuss procedure for repair of pectus excavatum}

\section{I.I. Myhal}

Danylo Halytsky Lviv National Medical University, Ukraine

Introduction. The hemodynamic parameters during the Nuss procedure for repair of pectus excavatum are under the influence of surgical procedures and anesthetic components especially regional blocks.

The aim of the study: analysing the hemodynamic parameters during the Nuss procedure for repair of pectus excavatum under the combination of general anesthesia with different regional analgesia techniques. 


\section{Оригінальні дослідження. Торакальна та абдомінальна хірургія}

Materials and methods. The observative prospective study inclueded 60 adolescents (boys/girls=47/13) undergone the Nuss procedure for repair of pectus excavatum under the combination of general anesthesia with different types of regional blocks. The patients were randomized into three groups ( $n=20$ in each) according to the regional analgesia technique: standart epidural anaesthesia in the dermatome of maximal deformity (SEA), high epidural anaesthesia in Th2-Th3 level (HEA) and bilateral paravertebral anaesthesia (PVA). The deformity severity by Haller index in all patients was 3.9 [3.6-4.1]. The blood pressure (BP) and heart rate (HR) were analyzed at different stages of anesthesia and surgery.

Results. SEA resulted to significant derease in BP up to $30 \%$ compared to initial level before anesthesia. In the HEA group the decrease in BP was moderate and in PVA group the BP did not decrease at all. The sternal elevation and applying capnothorax increased BP without increasing HR. The bar rotation provided a little hemodynamic change in spite of being the most traumatic moment of such surgery. Under PVA HR was moderately increased but BP was almost unchanged, and the intraoperative infusion volume was the smallest in PVA group. HEA provided more stable hemodynamics in comparison to SEA. At the end of surgery hemodynamic parameters almost the same as initial before surgery.

Conclusions. During the Nuss procedure for pectus excavatum repair the blood pressure decreased significantly under the standart epidural anaesthesia in the dermatome of maximal deformity, moderately - under the high epidural anaesthesia in Th2-Th3 level and was stable under the bilateral paravertebral anaesthesia. HR decreased under epidural blocks but not under PVA. The sternal elevation and applying capnothorax increased BP. The initial hemodynamic parameters before surgery did not correlate with the severity of deformity according to the Haller index.

The study was conducted in accordance with the principles of the Helsinki Declaration. The study protocol was approved by the Local Ethics Committee of the institution. Informed consent of parents and children was obtained for the study.

The author declares no conflict of interest.

Key words: hemodynamics, pectus excavatum, Nuss procedure, epidural anaesthesia, paravertebral anaesthesia.

\section{Гемодинамика при коррекции воронкообразной деформации грудной клетки по Nuss \\ И.И. Мыгаль}

Львовский национальный медицинский университет имени Данила Галицкого, Украина

Актуальность. На гемодинамические показатели при коррекции воронкообразной деформации грудной клетки (ВДГК) по Nuss влияют как хирургические манипуляции, так и компоненты анестезии, особенно реґионарной.

Цель: исследовать анализ гемодинамических показателей при коррекции ВДГК по Nuss в условиях комбинации общей анестезии с разными вариантами реґионарных блокад.

Материалы и методы. В обсервационное проспективное исследование включено 60 подростков (мальчики/девочки $=47 / 13$ ), которые оперированы по поводу ВДГК в условиях комбинации общей анестезии с регионарными блоками. Пациенты рандомизированы на три группы по 20 в каждой в зависимости от метода реґионарного обезболивания: стандартная эпидуральная анестезия на уровне максимальной деформации (СЭА), высокая эпидуральная анестезия на уровне Th2-Th3 ВЭА) и билатеральная паравертебральная анестезия (ПВА). Тяжесть деформации по индексу Haller среди всех пациентов составила 3,9 [3,6-4,1]. Анализировали артериальное давление (АД), частоту сердечных сокращений (ЧСС).

Результаты. СЭА вызывала значительное снижение АДТ до $30 \%$ от исходного уровня до начала операции. В группе ВЭА снижение АД было менее выраженным. А в группе ПВА АД почти не изменилось под влиянием анестезии. Элевация грудины и капноторакс повысили АД без увеличения чСС. Момент поворота коррегирующей пластины незначительно влиял на гемодинамические показатели, хотя и считается найболее травматическим моментом данной операции. На фоне ПВА наблюдалось незначительная тахикардия, АД менялось минимально, и объем интраоперационной инфузии был найменьшим. ВЭА характеризовалась более стабильным гемодинамическим профилем, по сравнению с СЭА. В конце операции во всех группах гемодинамические показатели практически вернулись до исходного уровня.

Выводы. При коррекции ВДГК по Nuss снижение АД найболее выражено на фоне СЭА на уровне максимальной деформации, умеренное - на фоне ВЭА, и практически отсутствует - на фоне ПВА. СЭА вызывает снижение ЧСС, а ПВА практически не влияет на ЧСС. Элевация грудины, капноторакс сопровождаются некоторым повышением АД. Показатели гемодинамики перед операцией и анестезией у пациентов с ВДГК не коррелируют с тяжестью деформации по индексу Haller.

Исследование было выполнено в соответствиии с принципами Хельсинкской Декларации. Протокол иссследования согласован с Локальным этическим комитетом организации. На проведение исследования было получено информированное согласие родителей и детей. Автор заявляет про отсутсвтие конфликта интересов.

Ключевые слова: гемодинамика, воронкообразная деформация грудной клетки, операция Nuss, эпидуральная анестезия, паравертебральная анестезия.

\section{Вступ}

Лійкоподібна деформація грудної клітки (ЛДГК) трапляється з кількістю випадків від 1:300 до 1:1000 новонароджених та $€$ найчастішою деформацією грудної клітки (95-97\%), яка потребує хірургічної корекції [8]. Зміщення грудної клітки назад викликає стиснення камер серця, особливо правих відділів серця через більшу податливість до такого впливу [2]. За останні десятиріччя широко застосовується мініінвазивна методика корекції ЛДГК за Nuss [11], яка передбачає ретростернальне встановлення корегуючої пластини, яку потім повертають на $180^{\circ}$ та фіксують до грудної стінки. Така операція проводиться під відео-торакоскопічним контролем та потребує проведення капнотораксу для кращої візуалізації.
У анестезіологічному забезпеченні корекції ЛДГК за Nuss на сьогодні «золотим» стандартом вважається комбінація загальної анестезії з інтубацією трахеї та штучною вентиляцією легенів із торакальною епідуральною анестезією (ЕА). Традиційно катетеризацію епідурального простору проводять на рівні максимальної деформації з краніальним просуванням катетера приблизно на 3 cм [4]. Випадки неповної ефективності традиційної EA, особливо після корекції ЛДГК можуть бути пов'язані з особливостями інервації грудних м'язів, у якій $є$ частина нервів від плечового сплетіння. Окрім того, проведення катетеризації епідурального простору на рівні максимальної деформації інколи ускладнюється через змінену анатомію, а хід 
катетера та розповсюдження анестетика можуть бути непередбачуваними. Автор статті запропонував високу EA на рівні Th3-Th2 при корекції ЛДГК за Nuss, яку технічно легше виконати та теоретично вона блокує імпульси, що проходять через торакальні гілки плечового сплетіння. Подібну анестезію успішно застосовують в кардіохірургії [1]. Окрім епідуральної, при операції за Nuss успішно застосовують і білатеральну паравертебральну анестезію (ПВА) з катетеризацією [6].

На гемодинамічні показники під час операції за Nuss впливають як хірургічні маніпуляції, так і компоненти анестезії, особливо регіонарної. Вплив загальних анестетиків на гемодинаміку $є$ менш виразним, особливо при планових операціях. Проте, епідуральна анестезія викликає фармакологічну симпатектомію в зоні блокади, що впливає як на периферичний судинний спротив, так і на венозне повернення до правих відділів серця. На торакальному рівні епідуральна анестезія також впливає на симпатичну іннервацію серця [13]. Стосовно впливу паравертебральної анестезії на симпатичний тонус та венозне повернення до серця в літературі мало даних, проте з огляду на блокаду симпатичних гангліїв при ПВА, особливо білатеральній, можна очікувати такого ефекту.

Метою дослідження був аналіз гемодинамічних показників під час корекції ЛДГК за Nuss в умовах комбінації загальної анестезії з різними варіантами perioнарних блокад.

\section{Матеріали і методи дослідження}

Дослідження виконано в рамках науково-дослідної роботи кафедри анестезіології та інтенсивної терапії ФПДО Львівського національного медичного університету імені Данила Галицького «Клінікопатогенетичні аспекти анестезіологічного забезпечення оперативних втручань та інтенсивної терапії у хворих з порушенням гомеостазу» (державна реєстрація №0115U000049. Шифр роботи IH.21.06.0001.15). Позитивний висновок щодо дотримання принципів Гельсінської декларації, конвенції Ради Європи про права людини і біомедицину, ICH GCP та відповідних законів України отримано від комісії з біоетики ЛНМУ імені Данила Галицького (протокол №1 від 31.01.2018 р., головуючий д.мед.н., проф. А.Й. Наконечний).

До обсерваційного проспективного дослідження включено 60 пацієнтів, яким зроблено операцію корекції лійкоподібної деформації грудної клітки за Nuss на базі КНП ЛОР ЛОДКЛ «ОХМАТДИТ». Перед включенням у дослідження від пацієнтів та їх батьків було отримано інформовану згоду на участь в дослідженні. Критеріями включення у дослідження були вік від 10 до 18 років; наявність показань для корекції ЛДГК за Nuss, відсутність протипоказів для регіонарних методів знеболювання. Критеріями не включення до дослідження були протипокази або відмова від регіонарних методів знеболювання. Перед операцією дітей було рандомізовано на три групи за допомогою генератора випадкових чисел (https://www.random.org) у залежності від методу періопераційного знеболювання. Усім дітям проводилась загальна анестезія з інтубацією трахеї та штучною вентиляцією легенів. У якості загального анестетика застосовували пропофол, анальгетика - фентаніл, міорелаксанта атракурій для підтримання міорелаксації. Для інтра- та післяопераційної аналгезї застосовували регіонарні методи знеболювання: в групі CEA стандартну епідуральну анестезію с катетеризацією на рівні максимальної деформації (Th5-Th8), в групі ВЕА - високу епідуральну анестезію з катетеризацією на рівні Th2-Th3, та в групі ПВА - білатеральну паравертебральну анестезію з катетеризацією на рівні максимальної деформації. Для катетеризації як епідурального, так і паравертебральних просторів застосовували набори для епідуральної анестезії G18 (Періфікс, B.Braun, Німеччина). Епідуральний простір ідентифікували за методикою тесту втрати опору, паравертебральний - під УЗ-локацією. Катетер проводили краніально на глибину приблизно 3 см. Для інтраопераційної аналгезії застосовували бупівакаїн 0,5\% в усіх трьох групах. Після негативної аспіраційної проби та тест-дози довводили болюс розрахованої дози анестетика. Післяопераційне знеболювання забезпечувалось $0,25 \%$ розчином бупівакаїну з постійною інфузією 4 мл/год за допомогою еластомерної помпи в усіх групах протягом трьох діб. Катетери з епідурального та паравертебрального просторів видаляли на третій день після операції, після того, як пацієнтів переводили на пероральні анальгетики. Усі діти в схемі мультимодального знеболювання отримували внутрішньовенно парацетамол (60 мг/кг/добу) та нестероїдний протизапальний препарат (НПЗП).

Аналізували наступні параметри гемодинаміки: артеріальний тиск систолічний (АТсист), діастолічний (АТдіаст) та середній (АТсер), частоту серцевих скорочень (ЧСС). Тяжкість ЛДГК оцінювали за КТ-індексом Haller (IH), який визначають за формулою: максимальний поперечний діаметр грудної клітки: найвужчий передньо-задній діаметр (у нормі = 2,5) [7]. 


\section{Оригінальні дослідження. Торакальна та абдомінальна хірургія}

Таблиця 1

Характеристики пацієнтів по групах.

\begin{tabular}{|c|c|c|c|c|}
\hline Показник & Група СЕА & Група ВЕА & Група ПВА & \multirow{2}{*}{$\begin{array}{l}\text { Значущість різниці між } \\
\text { групами }\end{array}$} \\
\hline $\mathbf{n}$ & 20 & 20 & 20 & \\
\hline \multicolumn{5}{|c|}{ 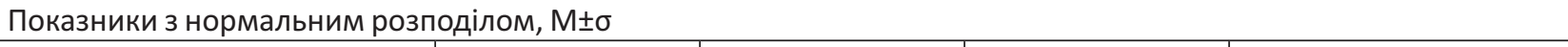 } \\
\hline Зріст, см & $166 \pm 10$ & $166 \pm 12$ & $166 \pm 7$ & $P=0,85$ \\
\hline Маса тіла, кг & $54,5 \pm 13$ & $55 \pm 11$ & $52,9 \pm 9$ & $P=0,86$ \\
\hline Індекс маси тіла & $19,5 \pm 2,7$ & $20,0 \pm 2,6$ & $19,2 \pm 2,6$ & $P=0,62$ \\
\hline \multicolumn{5}{|c|}{ Показники з ненормальним розподілом, медіана (25\% та 75\% перцентилі) } \\
\hline Вік, роки & $14,5(13-16)$ & $14(14-16)$ & $15(14-15)$ & $\mathrm{H}=0,10 ; p=0,81$ \\
\hline Стать (чоловіки/жінки), n (\%) & \begin{tabular}{|l}
$14 / 6$ \\
$(70 \% / 30 \%)$ \\
\end{tabular} & \begin{tabular}{|l}
$17 / 3$ \\
$(85 \% / 15 \%)$ \\
\end{tabular} & \begin{tabular}{|l}
$16 / 4$ \\
$(80 \% / 20 \%)$ \\
\end{tabular} & $H=1,35 ; p=0,51$ \\
\hline Індекс Haller & $3,8(3,5-4)$ & $3,9(3,6-4,6)$ & $3,8(3,6-4)$ & $H=1,92 ; p=0,38$ \\
\hline Фізичний статус за ASA, клас & $1(1-1,5)$ & $1(1-1,5)$ & $1(1-1)$ & $H=1,84 ; p=0,40$ \\
\hline Тривалість операції, хвилини & $85(80-90)$ & $85(80-90)$ & $80(75-90)$ & $H=0,19 ; p=0,91$ \\
\hline Об'єм крововтрати, мл & $70(55-75)$ & $60(55-80)$ & $70(70-80)$ & $H=2,78 ; p=0,25$ \\
\hline
\end{tabular}

Групи статистично не відрізнялись за демографічними, антропометричними та клінічними даними, а також за тривалістю операції та об'ємом крововтрати (табл. 1).

Статистичний аналіз отриманих даних проводився за допомогою програм Excel та Statistica 8.0 (StatSoft Inc., USA). Аналіз на нормальність розподілу проводили за допомогою тестів КолмогороваСмірнова, Lilliefors, Shapiro-Wilk. Для характеристики показників із нормальним розподілом визначали середнє значення (M) досліджуваних параметрів, стандартне відхилення (б), похибку середнього значення (m), та достовірність різниць між групами оцінювали за допомогою однофакторного дисперсійного аналізу. Для характеристики показників із ненормальним розподілом визначали медіану, 25\% та 75\% перцентилі, та міжгрупові відмінності оцінювали методом Крускала-Уолліса. Залежність між показниками визначалась за допомогою коефіцієнта кореляції Спірмена (R). Для

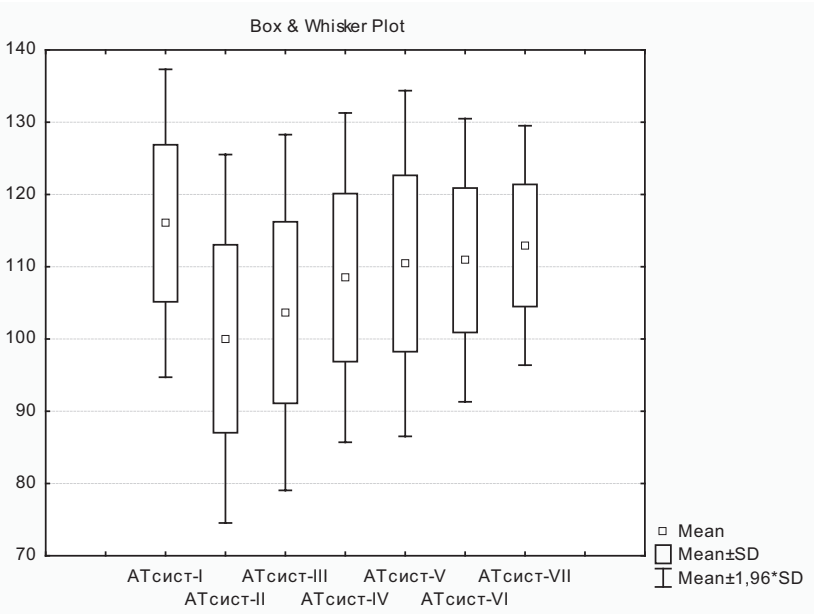

Рис. 1. Динаміка АТсист серед усіх пацієнтів, мм рт.ст. оцінки динаміки показників на етапах дослідження використали тест Уілкоксона. Різницю між величинами та кореляцію вважали статистично значущими при значенні $\mathrm{P}<0,05$.

\section{Результати дослідження}

Гемодинамічні показники аналізували на семи етапах анестезіологічного забезпечення та операції: 1 - до початку анестезії та операції в операційній, 2 - після введення в наркоз, інтубації трахеї та проведення регіонарної анестезії, 3 - після елевації груднини, 4 - після капнотораксу, 5 - після ротації корегуючої пластини, 6 - після екстубації трахеї, 7 - перед транспортуванням з операційної до стаціонарної палати.

Динаміка АТсист (рис. 1)

АТсист- 1 серед усіх пацієнтів на 1 етапі становив 119 [111-125] мм рт.ст. та не відрізнявся значно між групами (Kruskal-Wallis test: $\mathrm{H}(2, \mathrm{~N}=60)=0.11$; $\mathrm{p}=0,95)$. На 2 етапі введення в анестезію та регіонарні блоки викликали значне зниження АТсист-2 до 100 [90-110] мм рт.ст. (р<0,00001). Така динаміка АТсист була більш характерною для CEA: ATсист-2 знизився в групі СЕА на $18.1 \%$, в групі BEA на $14.8 \%$, та в групі ПВА - на 8.6\% (Kruskal-Wallis test: $\mathrm{H}(2, \mathrm{~N}=60)=8,06 ; \mathrm{p}=0,02)$. Елевація груднини підвищила АТсист-3 серед усіх пацієнтів до 107 [92-115] мм рт.ст. зі зберіганням значної різниці між групами (Kruskal-Wallis test: $\mathrm{H}(2, \mathrm{~N}=60)=6,4$; $\mathrm{p}=0,04)$. На етапі капнотораксу АТсист- 4 серед усіх пацієнтів дещо підвищився, але залишався значно нижчим, ніж на 1 етапі: 111 [100-118] мм рт.ст. (-6.7\% vs АТсист- $1 ; \mathrm{p}=0,00002)$, без значної різниці між групами (Kruskal-Wallis test: $\mathrm{H}(2, \mathrm{~N}=60)=3,85$; p=0,15). На етапі ротації корегуючої пластини під 


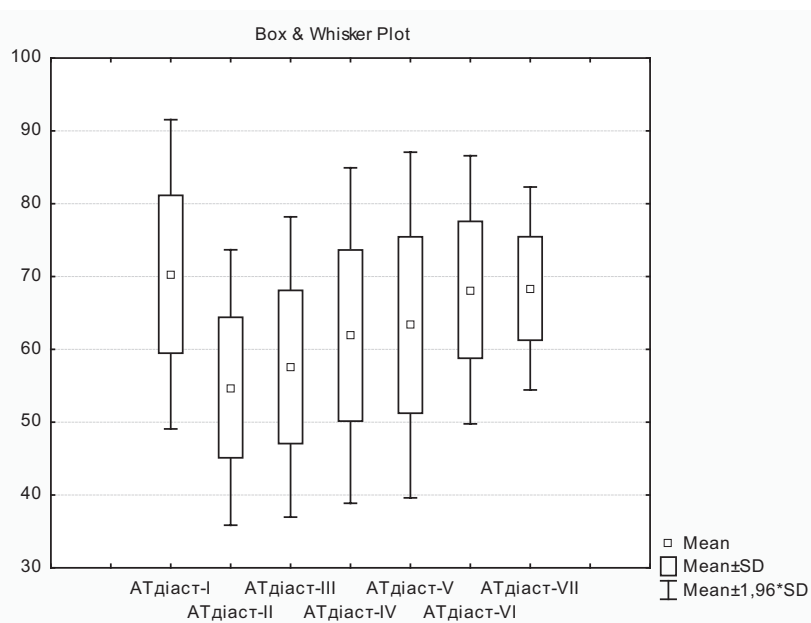

Рис. 2. Динаміка АТдіаст серед усіх пацієнтів, мм рт.ст.

торакоскопічним контролем спостерігалось подальше підвищення АТсист-5 до 115 [102-120] мм рт.ст., $з$ найвищим показником у групі ПВА 120 [116-124] мм рт.ст. (Kruskal-Wallis test: $\mathrm{H}(2, \mathrm{~N}=60)=15,0 ; \mathrm{p}=0,0005)$. Після екстубації трахеї АТсист-6 не зазнав значних змін порівняно 3 попереднім етапом, та міжгрупова різниця статистично незмінилася (Kruskal-Wallis test: $\mathrm{H}(2, \mathrm{~N}=60)=2,6 ; \mathrm{p}=0,28)$. Перед переведенням із операційної до палати в пацієнтів у повній свідомості АТсист-7 у середньому був вищим за вихідний рівень на $3,4 \%(\mathrm{p}=0,01)$ без значної різниці між групами (Kruskal-Wallis test: $\mathrm{H}(2, \mathrm{~N}=60)=1,1 ; \mathrm{p}=0,57)$.

Динаміка АТдіаст (рис.2)

Динаміка АТдіаст була аналогічною до АТсист на всіх етапах. Вихідний рівень АТдіаст-1 серед усіх пацієнтів становив 71 [65-80] мм рт.ст. без значної різниці між групами (Kruskal-Wallis test: $\mathrm{H}(2, \mathrm{~N}=60)=1,11 ; \mathrm{p}=0,57)$. Після початку анестезії та виконання регіонарних блокад АТдіаст-2 серед усіх пацієнтів знизився на $21 \%$ порівняно з 1 етапом $(\mathrm{p}<0,00001)$. Найбільше зниження АТдіаст-2 спостерігалось в групі CEA (-33\%), дещо менше - в групі BEA (-22\%), та найменше - в групі ПВА (-12\%) (Kruskal-Wallis test: $\mathrm{H}(2, \mathrm{~N}=60)=15,4$; $\mathrm{p}=0,0005)$. Елевація груднини викликала незначне підвищення АТдіаст-3, але він був значно нижчим за вихідний рівень $(\mathrm{p}<0,00001$ vs АТдіаст- 1$)$, зі зберіганням міжгрупової різниці (Kruskal-Wallis test: $\mathrm{H}(2, \mathrm{~N}=60)=14,8 ; \mathrm{p}=0,0006)$. Накладання капнотораксу викликало подальше підвищення АТдіаст-4 до 61 [54-70] мм рт.ст. ( $\mathrm{p}=0,00003$ vs АТдіаст-1), 3 найвищим показником у групі ПВА (KruskalWallis test: $\mathrm{H}(2, \mathrm{~N}=60)=16,0 ; \mathrm{p}=0,0003)$. Ротація корегуючої пластини не впливала на рівень АТдіаст-5. Після закінчення операції та екстубації тра-

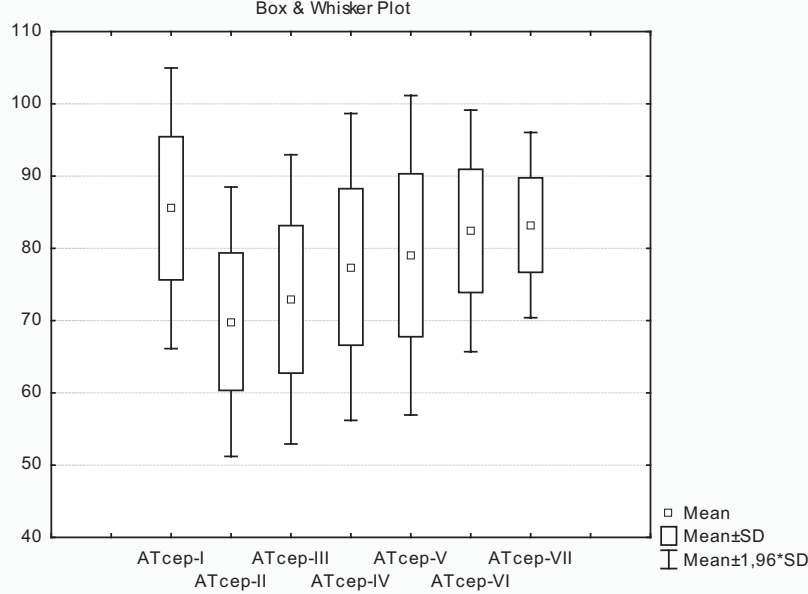

Рис.3. Динаміка АТсер серед усіх пацієнтів, мм рт.ст.

хеї АТдіаст-6 та при переведенні з операційної АТдіаст-7 тримався на рівні в середньому 70 мм рт.ст. ( $\mathrm{p}=0,1$ vs АТдіаст-1) без значної міжгрупової різниці (Kruskal-Wallis test: $\mathrm{H}(2, \mathrm{~N}=60)=4,1$; $\mathrm{p}=0,13)$.

\section{Динаміка АТсер (рис.3)}

Перед операцією та наркозом середній рівень ATcep-1 серед усіх пацієнтів становив 87 [79-94] мм рт.ст. без суттєвої різниці між группами (Kruskal-Wallis test: $\mathrm{H}(2, \mathrm{~N}=60)=0,64 ; \mathrm{p}=0,73)$. Початок загальної та регіонарної анестезії викликав зниження АТсер-2 на 19.5\% (p<0,00001), із суттєвою різницею між групами: у групі CEA на 26\%, у групі BEА на 19\%, та у групі ПВА на 11\% (KruskalWallis test: $\mathrm{H}(2, \mathrm{~N}=60)=16,6 ; \mathrm{p}=0,0002)$. На етапі елевації груднини АТсер-3 підвищився в середньому на 4,3\% порівняно з попереднім етапом, при цьому показник у групі дітей з ПВА залишався значно вищим порівняно з групами епідуральної анестезії (Kruskal-Wallis test: $\mathrm{H}(2, \mathrm{~N}=60)=13,8$; $\mathrm{p}=0,001)$. Після проведення капнотораксу АТсер-4 продовжував підвищуватись, та в середньому був на $9 \%$ нижчим за вихідний рівень ( $\mathrm{p}=0,000006$ vs ATcep-1). Ротація корегуючої пластини викликала ще деяке підвищення АТcep-5. На 4 та 5 етапах зберігалась міжгрупова різниця з найвищим показником у групі ПВА. Після закінчення операції та екстубації трахеї рівень АТсер-6 суттєво не відрізнявся між групами (Kruskal-Wallis test: $\mathrm{H}(2, \mathrm{~N}=60)=5,9 ; \mathrm{p}=0,053)$ та був вищим на $3,4 \%$ ніж вихідний рівень ( $\mathrm{p}=0,014$ vs ATcep-1). При переведенні з операційної до палати АТсер становив серед усіх пацієнтів 85 [81-87] мм рт.ст. ( $\mathrm{p}=0,054$ vs ATcep-1) та міжгрупова різниця була незначною (Kruskal-Wallis test: $\mathrm{H}(2, \mathrm{~N}=60)=3,2$; $\mathrm{p}=0,2)$. 


\section{Оригінальні дослідження. Торакальна та абдомінальна хірургія}

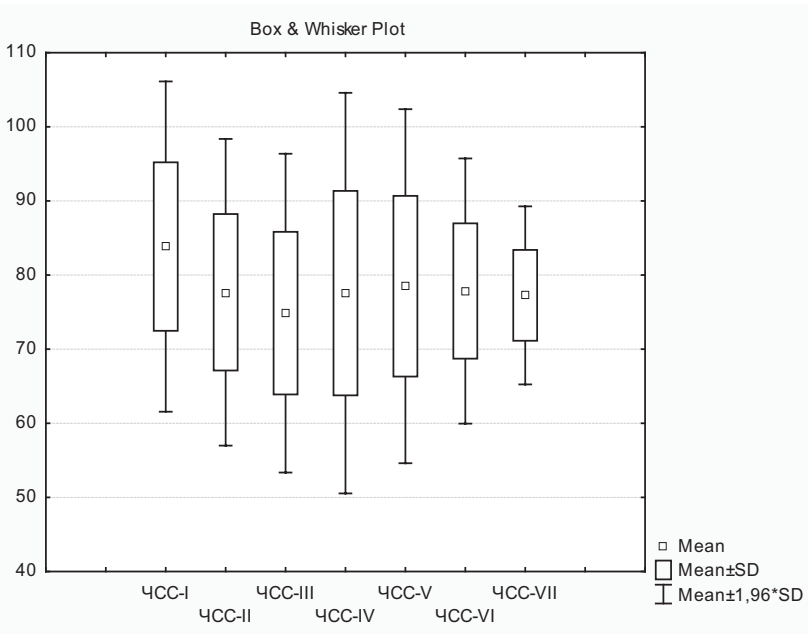

Рис. 4. Динаміка ЧСС серед усіх пацієнтів, ударів/хв.

\section{Динаміка ЧСС (рис. 4)}

На 1 етапі перед анестезією та операцією ЧСС-1 серед усіх пацієнтів у середньому становив 85 [7591] ударів/хв. та не відрізнявся суттєво між групами (Kruskal-Wallis test: $\mathrm{H}(2, \mathrm{~N}=60)=0,2 ; \mathrm{p}=0,90)$. Загальна анестезія з інтубацією трахеї та виконання perioнарних блоків викликало зниження ЧСС-2 на 10,6\% ( $\mathrm{p}=0,00003)$, але така тенденція була присутня тільки в групах епідуральної анестезії, тоді як в групі ПВА ЧСС-2 практично не відрізнявся від вихідного рівня (Kruskal-Wallis test: $\mathrm{H}(2, \mathrm{~N}=60)=10,7 ; \mathrm{p}=0,0047)$. Ha початку операції одразу після елевації груднини середня ЧСС-3 був на $14 \%$ нижчим за ЧСС-1 $\mathrm{p}=0,000007)$. Ці зміни відбулись тільки в групах CEA та ВЕА, тоді як в групі ПВА ЧСС-3 залишався без змін, порівняно з попереднім етапом (Kruskal-Wallis test: $\mathrm{H}(2, \mathrm{~N}=60)=17,5 ; \mathrm{p}=0,0002)$. Капноторакс викликав деяке підвищення ЧСС-4 у групах епідуральної анестезії, який залишався у середньому нижчим на $13 \%$, порівняно з вихідним рівнем ( $\mathrm{p}=0,0036)$. На етапі ротації корегуючої пластини така тенденція зберігалась. Лише перед транспортуванням із операційної до стаціонарної палати ЧСС-7 між групами значно не відрізнялася (Kruskal-Wallis test: $\mathrm{H}$ (2, $\mathrm{N}=60)=6,1 ; \mathrm{p}=0,05)$, та становила в середньому 77 [68-94] ударів/хв. ( $\mathrm{p}=0,000007$ vs ЧСС-1). У групі ПВА впродовж операції спостерігалась тенденція до помірної тахікардії.

\section{Кореляційні зв'язки між показниками}

Тяжкість деформації груднини визначали за КТіндексом Haller. Серед усіх пацієнтів значення IH до операції становило 3,91 [3,6 - 4,1] без суттєвої різниці між группами (Kruskal-Wallis test: H $(2, \mathrm{~N}=60)=1,92 ; \mathrm{p}=0,38)$. Вихідні показники гемодинаміки перед операцією та анестезією не корелюва- ли з тяжкістю деформації за IН: з АТсист-1 r=-0,031, $\mathrm{P}=0,81$; з АТдіаст-1 $\mathrm{r}=0,032, \mathrm{P}=0,80$; $~$ ATсер-1 $\mathrm{r}=0,012$, $\mathrm{P}=0,93 ;$; ЧCC- $1 \mathrm{r}=0,0018, \mathrm{P}=0,99$.

Об'єм інфузії впродовж операції (рис. 5) становив 1200 [1050-1400] мл серед усіх пацієнтів, та був найменшим у групі ПВА (Kruskal-Wallis test: $\mathrm{H}$ $(2, \mathrm{~N}=60)=8,34 ; \mathrm{p}=0,015)$. Застосовували ізотонічні кристалоїдні розчини. Потреби у вазопресорах в інтраопераційному періоді не було у жодного пацієнта.

Об’єм інтраопераційної інфузії мав зворотну кореляцію середньої сили з АТсист на 4 та 5 етапах, АТдіаст та АТсер на 3, 4 та 5 етапах та не корелював із показником ЧСС на жодному етапі дослідження (табл. 2).

\section{Обговорення}

Вплив операції малоінвазивної корекції ЛДГК за Nuss на гемодинамічні показники та кардіальну функцію досить жваво обговорюється в літературі, хоч на сьогодні немає єдиного бачення даної проблеми. Деякі автори доводять позитивний вплив такої корекції на серцевий викид та ударний об’єм серця, тоді як інші заперечують такий ефект $[5,9,10,14]$. Ця проблема набуває актуальності ще і через те, що при відсутності покращення кардіореспіраторної функції внаслідок корекції ЛДГК операція вважається суто косметичною, та страхові компанії не компенсують иї вартість пацієнтам [15]. Більшість досліджень гемодинаміки та серцевої функції у цих пацієнтів присвячені довготривалим ефектам корекції ЛДГК [3]. Для анестезіолога $є$ важливими гемодинамічна стабільність під час операції, яка безпосередньо впливає на камери серця, та оцінка впливу методів анестезії на стан гемодинаміки [12].

Порівняли гемодинамічний профіль під час корекції ЛДГК за Nuss на тлі комбінації загальної анестезії та трьох варіантів регіонарного знеболення: CEA на рівні максимальної деформації, BEA на рівнi Th2-Th3, та білатеральної ПВА. СЕА викликала значне зниження АТ до 30\% від вихідного рівня до початку операції. У групі BЕА зниження АТ було менш виразним. А в групі ПВА АТ майже не змінився під впливом анестезії. Таку різницю в гемодинамічних ефектах цих регіонарних блокад можна пояснити рівнем симпатичної блокади, яку вони викликають. Симпатектомія від CEА може розповсюджуватись як на торакальні, так і на абдомінальні сегменти. Тоді як ВЕА скоріше блокує симпатичну інервацію торакальної стінки та верхніх кінцівок. На тлі ПВА симпатична блокада можливо не є потужною, як на тлі епідуральної анестезії. Вплив хі- 
Таблиця 2

Кореляція між показниками гемодинаміки на етапах дослідження та інтраопераційним об'ємом інфузії.

\begin{tabular}{|c|c|c|}
\hline Показник гемодинаміки & Значення R & Значення P \\
\hline АТсист-1 & 0,08 & 0,54 \\
\hline АТсист-2 & 0,0095 & 0,94 \\
\hline АТсист-3 & $-0,24$ & 0,07 \\
\hline АТсист-4 & $-0,33$ & 0,01 \\
\hline АТсист-5 & $-0,43$ & 0,001 \\
\hline АТсист-6 & $-0,06$ & 0,64 \\
\hline АТсист-7 & $-0,11$ & 0,39 \\
\hline АТдіаст-1 & 0,013 & 0,92 \\
\hline АТдіаст-2 & $-0,27$ & 0,038 \\
\hline АТдіаст-3 & $-0,35$ & 0,005 \\
\hline АТдіаст-4 & $-0,41$ & 0,001 \\
\hline АТдіаст-5 & $-0,45$ & $<0,0001$ \\
\hline АТдіаст-6 & $-0,096$ & 0,47 \\
\hline АТдіаст-7 & $-0,26$ & 0,041 \\
\hline ATcep-1 & 0,039 & 0,77 \\
\hline ATcep-2 & $-0,18$ & 0,17 \\
\hline ATcep-3 & $-0,34$ & 0,008 \\
\hline ATcep-4 & $-0,41$ & 0,001 \\
\hline ATcep-5 & $-0,48$ & $<0,0001$ \\
\hline ATcep-6 & $-0,094$ & 0,47 \\
\hline ATcep-7 & $-0,24$ & 0,064 \\
\hline 4CC-1 & $-0,056$ & 0,67 \\
\hline 4CC-2 & $-0,15$ & 0,25 \\
\hline 4CC-3 & $-0,13$ & 0,30 \\
\hline ЧСС-4 & $-0,25$ & 0,057 \\
\hline 4CC-5 & $-0,28$ & 0,03 \\
\hline 4СС-6 & $-0,12$ & 0,35 \\
\hline 4СС-7 & $-0,098$ & 0,46 \\
\hline
\end{tabular}

рургічних маніпуляцій при корекції ЛДГК за Nuss на стан гемодинаміки починається з першого етапу - елевації груднини, яка практично усуває компресію камер серця. На даному етапі операції ми спостерігали підвищення АТ без збільшення ЧСС, що свідчить про те, що причиною такого ефекту не $\epsilon$ біль на тлі неадекватної аналгезії. Хоч ми і не знайшли кореляції між вихідними показниками гемодинаміки та тяжкістю деформації груднини за IH, покращення гемодинаміки після елевації груднини може свідчити про наявність компресії камер серця. Накладання капнотораксу викликало подальше підвищення АТ, що можливо пов'язане з підвищенням інтраторакального тиску та стисненням легенів. Момент повертання корегуючої пластини здійснив невеликий вплив на гемодинамічні показники, хоч i вважається найбільш травматичним моментом такої операції. Це свідчить про неадекватність анестезії. На тлі ПВА спостерігалось незначна тахікардія, АТ зазнав мінімальних змін, та об’єм інтраоперацій-

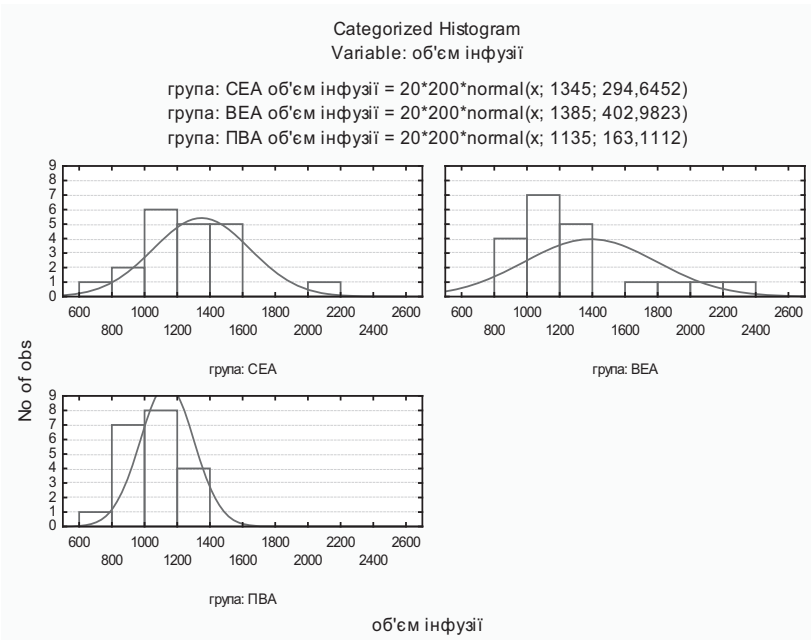

Рис. 5. Гістограми об'ємів інтраопераційної інфузії за групами, мл

ної інфузії був найменшим. BEА характеризувалась більш стабільним гемодинамічним профілем, порівняно з СЕА. Наприкінці операції в усіх групах гемодинамічні показники практично повернулись до вихідного рівня.

\section{Висновки}

На показники гемодинаміки під час корекції ЛДГК за Nuss впливають як методи анестезії, так і хірургічні маніпуляції.

CEА на рівні максимальної деформації характеризується найбільшим зниженням АТ, BEA на рівні Th2-Th3 викликає помірне зниження AT, та білатеральна ПВА викликає незначне зниження АТ. Епідуральна анестезія викликає зниження ЧСС, та ПВА практично не впливає на ЧСС.

Елевація груднини, капноторакс супроводжуються деяким підвищенням АТ.

Показники гемодинаміки перед операцією та анестезією у пацієнтів з ЛДГК не корелюють з тяжкістю деформації за індексом Haller.

Об'єм інтраопераційної інфузії має зворотну кореляцію з рівнем АТ під час операції. ПВА зменшує потребу в інтраопераційній інфузії.

У подальшій перспективі необхідно провести аналіз показників серцевого викиду, ударного об’єму та їх індексів на тлі різних регіонарних методів знеболювання при корекції ЛДГК.

Автор не має ніякого конфлікту інтересів.

References/Література

1. Chakravarthy M, Jawali V, Patil TA, Jayaprakash K, Kolar S, Joseph G, Das JK, Maheswari U, Sudhakar N. (2005, Jun). Conscious cardiac surgery with cardiopulmonary bypass using thoracic epidural anesthesia without endotracheal general anesthesia. J Cardiothorac Vasc Anesth. 19(3): 300-305.

2. Chao C-J, Jaroszewski D, Gotway M, Ewais MA, Wilansky S, Lester S, Unzek S, Appleton CP, Chaliki HP, Gaitan BD, Mookadam 


\section{Оригінальні дослідження. Торакальна та абдомінальна хірургія}

F, Naqvi TZ. (2018). Effects of Pectus Excavatum Repair on Right and Left Ventricular Strain. Ann Thorac Surg. 105: 294-301. http://dx.doi.org/10.1016/j.athoracsur.2017.08.017

3. Chao C-J, Jaroszewski DE, Kumar PN et al. (2015). Surgical repair of pectus excavatum relieves right heart chamber compression and improves cardiac output in adult patients-an intra-operative transesophageal echocardiographic study. Am J Surg. 210: 1118-2516.

4. Frawley G, Frawley J, Crameri J. (2016). A review of anesthetic techniques and outcomes following minimally invasive repair of pectus excavatum (Nuss procedure). Paediatr Anaesth. 26(11): 1082-1090. doi:10.1111/pan.12988. PMID:27510834

5. Guntheroth WG, Spiers PS. (2007). Cardiac Function Before and After Surgery for Pectus Excavatum. Am J Cardiol. 99: 17621764. doi:10.1016/j.amjcard.2007.01.064

6. Hall Burton DM, Boretsky KR. (2014). A comparison of paravertebral nerve block catheters and thoracic epidural catheters for postoperative analgesia following the Nuss procedure for pectus excavatum repair. Paediatr Anaesth. 24(5): 516-520. doi:10.1111/ pan.12369. PMID:24612096

7. Haller JA Jr, Kramer SS, Lietman SA. (1987). Use of CT scans in selection of patients for pectus excavatum surgery: a pre-liminary report. J Pediatr Surg. 22: 904-906.

8. Hebra A, Calder BW, Lesher A. (2016). Minimally invasive repair of pectus excavatum. J Vis Surg. 2: 73.

9. Jeong JY, Park HJ, Lee J, Park JK, Jo KH. (2014). Cardiac Morphologic Changes After the Nuss Operation for Correction of
Pectus Excavatum. Ann Thorac Surg. 97: 474-479. http://dx.doi.org/10.1016/j.athoracsur.2013.10.018

10. Maagaard M, Heiberg J. (2016). Improved cardiac function and exercise capacity following correction of pectus excavatum: a review of current literature. Ann Cardiothorac Surg. 5(5): 485492. doi:10.21037/acs.2016.09.03

11. Nuss D, Obermeyer RJ, Kelly RE. (2016). Nuss bar procedure: past, present and future. Ann Cardiothorac Surg. 5(5): 422-433. doi:10.21037/acs.2016.08.05

12. Patvardhan C, Martinez G. (2016). Anaesthetic considerations for pectus repair surgery. J Vis Surg. 2: 76. doi: 10.21037 /jovs.2016.02.31

13. Shagun Bhatia Shah, Uma Hariharan, Ajay Kumar Bhargava, Laleng M. Darlong. (2017). Anesthesia for minimally invasive chest wall reconstructive surgeries: Our experience and review of literature. Saudi J Anaesth. 11(3): 319-326. doi:10.4103/sja. SJA_13_17:10.4103/sja.SJA_13_17 PMCID: PMC5516496PMID: 28757834

14. Truong VT, Li CY, Brown RL, Moore RA, Garcia VF, Crotty EJ et al. (2017). Occult RV systolic dysfunction detected by CMR derived RVcircumferential strain in patients with pectus excavatum. PLoSONE. 12(12): e0189128. https://doi.org/10.1371/journal.pone.0189128

15. Zagrosek A et al. (2011). Hemodynamic impact of surgical correction of pectus excavatum - a cardiovascular magnetic resonance study.Journal of Cardiovascular Magnetic Resonance. 13(1): 190. doi:10.1186/1532-429X-13-S1-P190

\section{Відомості про автора:}

Мигаль Іван Іванович - аспірант каф. анестезіології та інтенсивної терапії ФПДО Львівського НмУ імені Д. Галицького. Адреса: м. Львів, вул. Пекарська, 69; тел.: +38 (032) 275-76-32. https://orcid.org/0000-0002-9786-538X

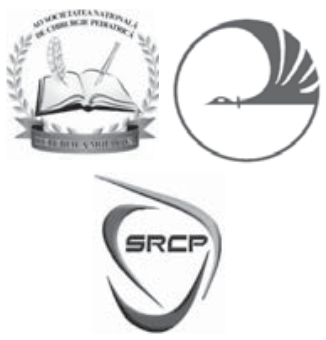

\section{PEDIATRIC SURGERY INTERNATIONAL CONFERENCE „PERFORMANCES AND PERSPECTIVES IN THE PEDIATRIC SURGERY DEVELOPMENT" \\ $2^{R D}$ Edition}

Chișinău, Republic of Moldova

27-29 May 2021

\section{Dear colleagues!}

It takes great pleasure, and we are honoured to invite you to participate at the $2^{\text {nd }}$ edition of the Pediatric Surgery International Conference "Performances and perspectives in the pediatric surgery development», which will take place on the 27-29"th of May 2021 in Chisinau, Republic of Moldova.

The goal of this scientific event is to bring together specialists in pediatric surgery, anesthesiology and intensive care, as well as from the connected specialities, and to discuss the new methods of diagnostic and treatment in pediatric surgery. We hope that valuable scientific discussions and opinions of the famous specialists in the field will encourage students, residents, young scientific researchers and doctors to take part actively at the meeting.

Besides the promising scientific program emphasized on the different problems of pediatric surgery, this is a unique occasion to get familiar with inimitable cultural and touristic heritage of this small and beautiful country, located in the southeast of Europe between Romania and Ukraine. Chisinau, for the first time mentioned in the ruler's chronicle in 1436, is the main administrative and cultural centre of our country, which always keeps its doors open for all guests visiting the Republic of Moldova.

We hope that this scientific meeting will have a high educational impact on our young colleagues, and will represent an excellent platform for communication between participants, as well as an opportunity of collaboration between specialists activating in this quite difficult field of medicine.

Stanislav Babuci, President of the National Society of Pediatric Surgery, Head of the Natalia Gheorghiu National Scientific and Practical Center of Pediatric Surgery of the Mother and Child Institute (Chisinau, Republic of Moldova)

Serghiu Gladun, Director of the Mother's and Child's Institute (Chisinau, Republic of Moldova

The registration will be online (www.sncprm.info.md)

Location: 93, Burebista Street, MD2062, Chisinau, Republic of Moldova

All papers and information about conference you can find on: www.sncprm.info.md 